\title{
Supporting Emerging States: Kosovo - Hungary Relations after the Independence of Kosovo
}

\author{
GÉCI-SHERIFI, Shkendije ${ }^{1}$
}

\begin{abstract}
Emergence of new states is a rather complicated concept of an international sys- tem that entails political as well as legal implications. As Danilo Turk clearly points out:

"Legal issues arising from dissolution of states, emergence of new states and rec- ognition of the latter require a thorough understanding of the relevant facts. While it is obvious that any legal discourse must proceed from firm factual foundations, it is necessary to emphasize the importance of the circumstantial dimensions of the issues, given that the views on the pertinent facts usually diverge, at least during the policy making stage". [1] Indeed, the recognition of emerging states needs a profound assessment and com-prehension of facts, historic and political circumstances, especially the factual reality; the latter sometimes supersedes eventual legal disputes. However, the fac-tual reality, if legitimate, as in the case of Kosovo is something that should not be ignored but rather supported, especially in the state building process. Hence, the paper will give a depiction of the case of the independence of Kosovo as a sui generis case, and will continue with an outline of the Hungarian support, namely the evolvement of Kosovo-Hungary bilateral relations after the declaration of independence. The paper will tend to highlight the fact that the support of Kosovo as an emerging state, serves peace and long-term stability, regional development and other integration processes. It contributes to regional security, as well.
\end{abstract}

\section{Introduction}

In the 1990's the political events in Europe and other parts of the world caused boarder changes in many countries. The Berlin Wall collapsed, East and West Germany were united after many years of division. These years note the dissolution of the Soviet Union and con- sequently the emergence of twelve independent states. It is this period that also marks the beginning of the disintegration of the Socialist Federative Republic of Yugoslavia ${ }^{2}$ which due to interethnic tensions and unsolved issues led to a bloody war. Peace agreements were concluded after the wars in Yugoslavia and these resulted in full international recognition of the new states. The creation of these states was legally supported by the Arbitration Commit- tee known as the Badinter Commission which was set up by the Council of Ministers of the European Economic Community (EEC) on 27 August 1991. [2] The purpose of this commis- sion was to provide legal advice and criteria for recognition to former Yugoslav republics.

1 Ambassador of Kosovo to Hungary, email: shkendije.geci@gmail.com

2 Yugoslavia consisted of six republics: Slovenia, Croatia, Bosnia and

Herzegovina, Serbia, Montenegro and Macedonia and two autonomous provinces Kosovo and Vojvodina 
The case of recognition of Kosovo however was far more legally and politically complicated, even though both, Kosovo and Vojvodina, after the constitution of 1974 were largely equal to the republics of the Yugoslav federation. Kosovo declared its independence in 2008.

The case of Kosovo is a sui generis case for a number of reasons: first, Kosovo was con- fronted by systematic and contionous human righs violations for many years by the regime of Slobodan Milosevic. Second, the intervention of NATO was a humanitarian one. Third, Kosovo was under UN administration according to resolution 1244 that provided a legal and constitutional framework that created all parameters, features and preconditions for a new state. Furthermore, the International Court of Justice (ICJ) confirmed that the declaration of independence did not vioate international law. Supporting independence for the Republic of Kosovo was therefore the right step to take, and Hungary along with the majority of EU and NATO members with this support put down the cornerstone to peace and stability in the Balkans.

\section{Declaration of independence and formal recognition}

On 17 February 2008, the Parliament of Kosovo declared Kosovo an independent and sover- eign state. The Government of the Republic of Kosovo pledged to comply with the Ahtisaari Plan given that the lengthy process of negotiation and diplomatic efforts did not succeed either to bridge the gap between Kosovo and Serbia or to secure a new resolution within the UN Security Council. The declaration, the independence as such, was unilateral however; this action was taken in full consultation and accordance with international actors, namely the US and the majority of the most eminent European states. The Republic of Kosovo, up to now, has been recognised formally by 108 states out of 193 UN Members, 3 out of 5 UN Security Council (UNSC) Permanent Member States, 23 out of 28 European Union (EU) Member States, 24 out of 28 NATO Member States. [3] The Republic of Kosovo is a full member of the The World Bank, International Monetary Fund, and the International Bar Association. [3]

\section{International Court of Justice's advisory opinion on Kosovo}

The International Court of Justice, with a compelling vote of ten to four, advised on 22 July

2010 "that the declaration of independence of Kosovo adopted on 17 February 2008 did not violate international law". [4: para. 123 (3)] Basically, the court concluded that the "that the declaration of independence of 17 February 2008 did not violate general international law". [4: para. 84] Furthermore, the Court's advisory opinion was clear as far as the UN Security Council Resolution (UNSCR) 1244 was concerned, as it stated that: "the declaration of inde- pendence did not violate Security Council resolution 1244(1999)" it reaffirmed that UNSCR

1244 "was essentially designed to create an interim regime for Kosovo... [4: para. 119] The resolution did not contain any provision dealing with the final status of Kosovo." [4: para. 114] These statements of the court clearly confirmed that the Declaration of Independence is legal and legitimate. The ICJ went further on to declare that the circumstances that led to the Dec- laration of Independence of the Republic of Kosovo are exceptional; unique, therefore the case of Kosovo is sui generis. 
The Court presented factual and legal circumstances that are unique to Kosovo and those are: non-consensual and violent break-up of former Yugoslavia; the adoption of UNSCR

1244 to put an end to armed conflict in order to resolve the humanitarian crisis in Kosovo; the period of UN interim administration; and the exhaustion, after many years, of all avenues for a negotiated solution with the Government of Serbia. [5] This pattern of facts applies only to Kosovo. The specificity of the Court's ruling cannot serve as a precedent for other situations. This means that, efforts to portray the Court's decision as "opening Pandora's Box" are mis- leading and incorrect. [5]

\section{Kosovo-Hungary Relations after the Independence of Kosovo}

Considering the status quo and the prolonged UNMIK administration in Kosovo was not sustainable anymore in relation to the newly created reality in Kosovo after the declaration of independence on 17 February, 2008, and having seen that the diplomatic efforts to attain an optimal mutually accepted solution from both sides were exhausted, the Government of Hungary, in its session of March 19, 2008, decided to recognise the independence of the Republic of Kosovo. Consequently, the Minister of Foreign Affairs, Göncz Kinga requested the presentation of the proposal to the President of the Republic of Hungary, Sólyom László to establish diplomatic relations with Kosovo. [6] This stance of Hungary was in compliance with the majority of EU countries while this foreseeable step was proclaimed even before. During the Visegrad summit in Ostrava, in the Czech Republic, the prime minister of Hun- gary at that time, Gyurcsány Ferenc stated that Kosovo's drive towards independence is irreversible, adding that independence should occur with the EU's assistance. He stressed that no peace can be maintained in the Balkans without the realistic options of autonomy and independence while Kosovo is an EU matter and should not be abandoned. The prime minister expressed his belief that there was a good chance for the European Union member states to establish a common denominator regarding the future of Kosovo. [7] The Hungarian foreign policy towards Kosovo reflected a clear position: [8] the independence of Kosovo serves peace and long term stability, regional development and other integration processes. The ICJ advisory opinion will not affect the supportive approach of Hungary towards Koso- vo. With the recognition of Kosovo, Hungary was in line with the standpoints of the majority of EU and NATO member states. The resolution of the final status of Kosovo constitutes a sui generis case that did not create a precedent in other unresolved situations. Hungary con- sidered the principles and values determined in the Ahtisaari Plan such as democracy, rule of law, market economy and above all the rights of ethnic communities as highly important. Hungary followed the implementation of these principles through the International Steering Group for Kosovo (ISG). ${ }^{3}$ Hungary valued the readiness of the Kosovo leadership to closely cooperate with the International Community. Most importantly, Hungary contributed and continues to contribute to the increase of regional stability and security amongst others with its participation in KFOR and EULEX.

3 The International Steering Group for Kosovo (ISG) was an organization formed pursuant to the Ahtisaari Plan concerning the Kosovo status process. It was set up to guide Kosovo's democratic development and promote good governance, multi-ethnicity and the rule of law. 
The FIDESZ ${ }^{4}$ win of the general elections of 2010 in Hungary did not change the foreign policy towards Kosovo, on the contrary, the intensification of bilateral relations and support was deepened in the years to come. It is important to stress that the Government of Hungary was always clear in its relations with Kosovo and Serbia given the political sensitivity of rela- tions with the latter. It has always considered the relations with both countries as very import- ant but separate at the same time. Hungary is fully engaged in advancing bilateral relations with Serbia and has stated that the recognition of independence should not be an obstacle in these relations, while it considers that Kosovo issues should not affect the development of the relations between Serbia and the EU. Being a neighbouring country of Serbia, Hungary is committed to support Serbia in its EU integration path.

During the Hungarian EU Presidency, one of the most important topics of the agenda from the perspective of Kosovo, certainly was the support of EU enlargement and good neighbourly relations policy. This approach was welcomed from Kosovo as Hungary sup- ported the further enlargement process trying to ensure thus an integration perspective for the Western Balkans. In this context, the conclusion of accession negotiations for Croatia, has been highly positive and hopeful and an inspiration for Western Balkans countries. In this light, the statement of the State Secretary, Németh Zsolt, that the accession of Croatia was possible, ultimately suggests that the accession of other Western Balkans countries is possi- ble too, including Kosovo and so this was very encouraging. [9]

The deepening and advancement of bilateral relations and the continuous Hungarian sup- port have further strengthened the subjectivity of the statehood of Kosovo. The bilateral relations between Kosovo and Hungary experienced an immense intensification especially after the establishment of the Embassy of Kosovo in Budapest in early 2010. These relations marked the realization of high level bilateral visits ${ }^{5}$, a high number of bilateral agreements ${ }^{6}$ were signed, many more were initiated while there was a continuous exchange and cooper- ation in different projects. Hungary, being an excellent example of successful transition and integration had a lot of expertise to offer and it demonstrated this through continuous support and guidance in different projects, and other forms of collaboration.

\section{From political cooperation towards the economic one}

As it is widely known, economic diplomacy is a driving force of relations between states. Slowly but surely, the relations of Hungary and Kosovo started to pave the path in the eco- nomic direction, as well. One of the highly significant activities that marked an advancement of bilateral relations beyond a political dimension was the organization of the Economic Fo- rum under the patronage of the Prime Minister of Kosovo, Hashim Thaci, as a part of Koso- vo's Government for investment promotion. ${ }^{7}$ The Economic Forum took place in Budapest with the presence of the Hungarian Prime Minister, Orbán Viktor. The key objective of this Forum was to promote investments in Kosovo and to boost economic and trade cooperation between Kosovo and Hungary. This event, apart from the highest political representation,

4 Federation of Young Democrats-Hungarian Civic Alliance, Fiatal Demokraták Szövetsége-Magyar Polgári Szövetség

5 See annex I for the chronological list of high level bilateral visits.

6 See annex II the list of bilateral agreements in the annex of this paper.

7 Economic Forum was facilitated and organized by the Embassy of Kosovo in Budapest in 13 June 2012 
gathered a high number of business representatives from Hungary and Kosovo. In addition, in the margins of this rather big event, three important agreements in the field of trade and economy were signed:

1. Cooperation Agreement between Customs of Kosovo and Tax Administration and Customs of Hungary;

2. Cooperation agreement between Kosovo Agency for Investment Promotion and Hun- garian Agency for Trade and Investment;

3. Cooperation Agreement between Kosovo Economic Chamber and Hungarian Cham- ber of Trade and Economy.

The signing of the respective agreements is firstly important for the support of economic activities of both countries, secondly important for the encouragement of the effective coop- eration of the business community and thirdly the agreement is important for the promotion of concrete and efficient collaboration of business representatives. These factors along with strong political support, were clear indicators that Kosovo and Hungary were moving on the right track and will provide fruitful results in the economic field in the very near future. Hungary and Kosovo at the political level agreed to foster economic relations and to fur- ther explore market and cooperation possibilities. This particular economic forum gathered around 160 participants out of which around 80 business representatives were from Hungary and 30 from the Republic of Kosovo. Hungary has pledged economic cooperation with the Western Balkans, Kosovo in particular. Accordingly, in the framework the Hungarian Cham- ber of Commerce, it created the Committee for Western Balkans responsible for promoting economic relations with the countries of the Western Balkans. Consequently, in order to come to more concrete terms of economic cooperation, the Embassy of Kosovo in Budapest, on December, 2013 in cooperation with the Hungarian Chamber of Commerce and Industry supported by the Ministry of National Economy of Hungary organized the second economic forum in Budapest as a follow up of the previous economic forum with the primary aim to update the Hungarian business community and other interested parties with the privatization offers in Kosovo as well as the business climate and investment opportunities in the Republic of Kosovo. Conclusively, diplomatic relations between Kosovo and Hungary at the political level are excellent while at the economic level, more efforts should be invested in order to bring them to the mutually desired level. Hungarian investments and export is mainly on infrastructure, IT, construction and food products. According to Orosz György, director of the department for Global Economy, Ministry of National Economy of Hungary, in 2010, Hungarian export to Kosovo was 27.1 milion euro while Kosovar export to Hungary was 0.1 milion euro. [10] In 2011, Hungarian export to Kosovo was 31.8 milion euro whereas Koso- var export to Hungary was 0.2 milion euro. In 2012, Hungarian export to Kosovo was 31.4 milion euro whereas Kosovar export to Hungary was 0.15 milion euro. In 2013, Hungarian export in Kosovo was 32 million euro whereas Kosovo's export to Hungary was 0.6 (the figures of 2013 are approximate, they will be exact in 2014). Advancement through the years has been noted, however, both countries believe it should be upgraded in the future. 


\section{Conclusion}

According to international law the international legal criteria of statehood are: a) a perma- nent population b) a defined territory c) government and d) capacity to enter into relations with other states. The Arbitration Commission of the European Conference on Yugoslavia in Opinion No. 1 in a similar way declares that " the State is commonly defined as a community which consists of a territory and a population subject to an organised political authority" and that "such a State is characterized by sovereignty". [11] The above mentioned criteria are clearly met in the case of Kosovo and the righteous act of recognition concords with the majority of EU and NATO member states and support only increases security, peace and stability. The best supportive approach of an emerging state such as Kosovo is luminously described through a metaphor used by Tóth Zoltán in the article: Kosovo by the authority of ballot, not the force of the bullet, which states that:

“After conception the new life grows in the mother's womb. The 'nasciturus'state is fol-lowed by the birth of a new person or by nothing. The newborn baby tries to adapt, forced by the new conditions. The parents are usually happy but the neighbours are not always glad with the newcomer. Once, a phrase is heard from a relative: "the baby is walking, is he...!" Can a born baby be considered non-existent? The world says clearly: someone born shall live! But, under what circumstances? Starving and in dictatorship? The minimal expectation of an idealist is starving and in a democracy. The opinion of relatives is variable. Their indi-vidual interests form their standpoint. The doctor involved in the birth, the midwife, and then the nursery and kindergarten educator, the school teacher, as EXPERTS no longer look for the cause of existence but the quality of life: what will this kid become? Will he become an ambitious useful person, or ballast that needs support and solicitude?!”[12]

As this metaphoric paragraph indicates and is described in this paper, the emergence of new states as well as their recognition need a profound understating of not only the legal as- pects, but legitimacy along with political and historic circumstances, as well. Factual reality should not be ignored but rather approached constructively with the aim of upholding the values of democracy, whilst marinating peace and stability. Therefore, the establishment of diplomatic relations between Kosovo and Hungary, is a constructive approach and with co- operation at all levels contributes to the further development of a stable, European-oriented, multi-ethnic and democratic state of Kosovo. 


\section{Annex I:}

HIGH LEVEL BILATERAL VISITS [13]

- December 22, 2011 Hungarian President Mr. Schmitt Pál visited Hungarian military units within the KFOR and met with President Jahjaga;

- January 18-19, 2012 Official visit of the President of the Parliament Mr. Kövér László in Prishtina;

- April, 2012 Protection and the Rule of Law Commission of the National Assembly of Hungary visits Prishtina;

- September 10, 2012 State Secretary for Foreign Affairs Mr. Németh Zsolt took part in the completion of supervised independence by the International Steering Group (ISG);

- November 16-17, 2012 Minister for Rural Development Mr. Fazekas Sándor visits Kosovo;

- April 08-09, 2013 Political Director of MFA Mr. Sztáray Péter, visits Kosovo;

- April 10-11, 2013 Chairman of the Foreign Affairs Committee of Parliament Mr. Balla Mihály visits Kosovo;

- November 26-27, 2013 Vice President of the National Assembly of Hungary Mr. La- torcai János, visits Prishtina on the occasion of the conclusion of the twinning program with Kosovo Assembly funded by the EU;

- December 12-14, 2013 Visit of the Minister of Defense Mr. Hende Csaba to meet Hungarian soldiers serving in the KFOR;

\section{VISIT OF SENIOR OFFICIALS OF KOSOVO TO HUNGARY}

- February 20, 2010 Minister of Agriculture and Rural Development Mr. Idriz Vehapi's official visit to Hungary;

- March 29-30, 2011 Official visit of Chairman of Parliament Mr. Jakup Krasniqi in Hungary;

- June 3, 2011 Official visit of Minister for European Integration Miss.Vlora Citaku in Budapest;

- September 14, 2011 President of the Republic of Kosovo Ms. Atifete Jahjaga conducted an official visit to Budapest;

- October 11, 2011 Chairman of Parliament Mr. Jakup Krasniqi takes part in the fifth Conference of the Parliaments of the Western Balkan countries in Budapest;

- February 27-28, 2012 Visit of the Mayor of Prishtina Mr. Mustafa in the municipality of Budapest;

- June 13, 2012 Kosovo Republic's Prime Minister Mr. Hashim Thaci opens the Eco- nomic Forum "Business and Investing in Kosovo" in Budapest and met Hungarian Prime Minister Mr. Viktor Orban. The forum was also attended by the Minister of Economic Development Mr. Besim Beqaj and Minister of Trade and Industry Ms. Mimoza Kusari Lila;

- May 24-25, 2013 Minister of Public Administration Mr. Mahir Yagcilar visited Hun- gary;

- October 8, 2013 Chairman of Parliament Mr. Jakup Krasniqi takes part in the sixth Conference of the Parliaments of the Western Balkan countries in Budapest; 
- October 8, 2013 Minister of Environment and Spatial Planning Mr. Dardan Gashi took part in the World Water Summit in Budapest;

- October 31, 2013 Vice Foreign Minister Mr. Petrit Selimi attended the summit of the Visegrad Group on the Western Balkans;

- November 11-12, 2013 Minister of Agriculture and Rural Development, Mr. Blerand Stavileci visited Hungary;

- 10-12 February 2013 Minister of Diaspora Mr.Ibrahim Makolli visited Hungary;

\section{MEETINGS OF SENIOR KOSOVAR AND HUNGARIAN OFFICIALS AT MULTI- RATERALEVENTS}

- September 26, 2012 Foreign Ministers Mr. Enver Hoxhaj. and Mr. János Martonyi meet on the margins of the session of the General Assembly of the UN;

- November 23, 2012 Foreign Ministers Mr. Enver Hoxhaj. and Mr. János Martonyi meet on the margins of the Conference of the Aspen Institute in Berlin;

- April, 2013 European Integration Minister Miss.Vlora Citaku meet with Secretary of State for EU Affairs Ms. Eniko Győri in Brussels;

\section{Annex II}

KOSOVO HUNGARY BILATERAL AGREEMENTS AND THEIR STATUS ${ }^{8}$ : Implemented:

- Repatriation Agreement;

- Agreement on cooperation between the National University Library of Kosovo and the National Library of Hungary;

- Agreement of Cooperation on Customs;

- Memorandum of Cooperation between the Chamber of Economy and Industry of Hun- gary and Kosovo Chamber of Commerce;

- Cooperation Agreement for the fight against terrorism, drug trafficking and organized crime;

- Memorandum of Cooperation between the Agency for Investment Promotion of Koso- vo and the Hungarian Agency for Investment and Trade;

- Agreement on the Elimination of Double Taxation;

- Cooperation Agreement between the Central Election Commission of Kosovo and the Association of European Election Officials ACEEEO;

- Cooperation Agreement between the University of Prishtina and the Corvinus Univer- sity of Budapest;

- Cooperation Agreement between the University of Prishtina and St. István Univeristy, Gödöllö;

- Agreement for Cooperation between the public television of Hungary and Republic of Kosovo;

8 Idem 
- Cooperation Agreement between the German speaking Andrássy University and the University of Prishtina;

- Cooperation agreement between the Hungarian Office for Migration and the Depart- ment of Citizenship, Asylum and Migration of the Ministry of Interior of Kosovo;

- Cooperation agreement between the Kosovo Diplomatic Academy and the Hungarian Institute for International Relations;

\section{EXPECTED TO BE SIGNED:}

- Agreement on Mutual Legal Assistance in Criminal Matters (initiated by the Kosovo side, negotiations have begun);

- Agreement of Cooperation in the field of European integration initiated, expected sig- nature);

- Agreement on international transport of passengers and goods (expected signature);

- Agreement of Cooperation between the National Museum of Hungary and Kosovo Museum (initiated, expected signature);

- Cooperation agreement between the Kosovo Authority of Civil Aviation and Civil Avi- ation Authority of Hungary (initiated, expected signature);

- Cooperation agreement between the University of Pristina and Semmelweis Universi- ty (medicine) (initiated, expected signature);

- Cooperation between the Institute for Social and European Studies of Corvinus Uni- versity and embassy of Kosovo in Budapest (initiated, expected to formalize cooper- ation);

\section{EXPECTED TO BE NEGOTIATED:}

- Agreement on Extradition (initiated by the Kosovo side, there is a positive response from Hungary to begin negotiations);

- Agreement on Transfer of Sentenced Persons (initiated by the Kosovo side, there is a positive response from Hungary to begin negotiations);

- Visa abolition agreement by holders of diplomatic passports; (initiated by the Kosovo side, expected response from the Hungarian side);

- Agreement on cooperation between the Ministry of Defence of Hungary and the Min- istry of Kosovo Security Force (initiated);

- Cooperation agreement between the University of Prishtina and ELTE University of Budapest (initiated, expected negotiation);

- Cooperative agreement between the National Archives (initiated by Kosovo Embassy in Hungary, expected negotiation);

\section{TO BE INITIATED:}

- Economic cooperation agreement, which preceded the creation of the Joint Economic Commission (expected to be initiated soon by Kosovo Embassy in Hungary);

- Agreement for cooperation in the field of education between the Ministries of Educa- tion in both countries (expected to be initiated soon by Kosovo Embassy in Hungary);

- Cooperation between Central Office for Administrative and Electronic Public Services (MIA) and the Civil Registry Agency of Kosovo (MIA) (expected to be initiated soon by Kosovo Embassy in Hungary); 
GÉCI-SHERIFI, Shkendije: Supporting Emerging States: Kosovo — Hungary Relations...

- Cooperation Agreement between the State Agency for Personal Data Protection Au- thority of Kosovo and the Hungarian National Data Protection and Freedom of Infor- mation (expected to be initiated soon by Kosovo Embassy in Hungary);

- Cooperation Agreement between Emergency Management Agency (MIA) and the Na- tional Emergency Management Hungary (MIA) ;

\section{References}

[1] TURK, D.: Recognition of States: A Comment. European Journal for International Law 4 (1993), 66-71.

[2] For more information on the Arbitration Commission of the Peace Conference on Yugoslavia see: www.en.wikipedia.org/wiki/Arbitration_Commission_of_the_Peace_Conference_on_Yugoslavia (downloaded: 0304 2014)

[3] www.kosovothanksyou.com/statistics (downloaded: 0404 2014) [4] Opinion.

[5] Position of the Republic of Kosovo on the International Court of Justice Advisory Opinion. Accordance with International Law of the Unilateral Declaration of Independence in Respect of Kosovo, 22 July 2010.

[6] Hungary recognizes Kosovo's Independence. Ministry of Foreign Affairs of Hungary, 1903 2008. https://doi.org/10.1093/oxfordjournals.ejil.a035855

[7] MEZES D.: Hungary is the $17^{\text {th }}$ country recognising independent Kosovo. www.cafebabel. co.uk/budapest/article/hungary-is-the-17th-eu-country-recognizing-the-independent-kosovo. html (downloaded: 0304 2014)

[8] Kosovo Hungary Relations: Memorandum. Reference number: 144 dmd/2010 MFA Kosovo

[9] Personal meeting with State Secretary, Németh Zsolt. MFA Budapest, 2011. [10] Source:

Economic Forum II Report, Embassy of Kosovo in Budapest.

[11] NURULLAH, Y.: What is meant by state recognition in international law? www.justice.gov. tr/ejournal/pdf/LW7081.pdf (downloaded: 3003 2014)

[12] TÓTH Z.: Kosovo by the authority of ballot, not the force of the bullet. Independence of the Electoral Management Bodies. In Focus: Kosovo. Journal Elections in Europe, 7 28. [13] Source:

Embassy of Kosovo in Budapest. 